\title{
PCR Multipleks untuk Identifikasi Mycobacterium tuberculosis Resisten terhadap Isoniazid dan Rifampisin pada Galur Lokal Balai Laboratorium Kesehatan Provinsi Jawa Barat
}

\section{Multiplex PCR for Identification the Isoniazid- and Rifampin-resistant Mycobacterium tuberculosis (Local Strain of Balai Laboratorium Kesehatan Provinsi Jawa Barat)}

\author{
Iman Permana Maksum ${ }^{1}$, Suhaili ${ }^{1}$, Rizki Amalia ${ }^{1}$, Dian Siti Kamara ${ }^{1}$, Saadah Diana \\ Rachman $^{1}$, Rifky W Rachman ${ }^{2}$ \\ ${ }^{1}$ Departemen Kimia Fakultas Matematika dan Ilmu Pengetahuan Alam Universitas Padjadjaran \\ ${ }^{2}$ Balai Laboratorium Kesehatan Provinsi Jawa Barat \\ Email: iman.permana@unpad.ac.id
}

Received: February 2018; Revised: July 2018; Accepted: September 2018; Available Online: November 2018

\begin{abstract}
Abstrak
Timbulnya kasus multidrug resistant tuberculosis (MDR-TB) menjadi permasalahan terbesar dalam upaya pemberantasan penyakit tuberkulosis (TB) di Indonesia. MDR-TB merupakan kasus bakteri yang resisten minimal terhadap dua jenis obat anti tuberkulosis (OAT) lini pertama, yakni rifampisin dan isoniazid. Berbagai metode diagnosis yang digunakan saat ini belum dapat mengidentifikasi kasus MDR-TB dengan cepat, spesifik, dan akurat. Tujuan penelitian ini adalah mengidentifikasi M. tuberculosis (galur lokal Balai Laboratorium Kesehatan Provinsi Jawa Barat) yang resisten terhadap isoniazid dan rifampisin (MDR-TB) dengan menggunakan PCR multipleks. Metodologi penelitian yang digunakan adalah kultivasi bakteri TB pada media middlebrook $7 \mathrm{~h} 9$ broth, isolasi DNA kromosom bakteri TB, optimasi kondisi PCR, amplifikasi dengan PCR multipleks menggunakan pasangan primer inh $\mathrm{A}_{1}$-inh $\mathrm{A}_{2}, \mathrm{rpoB}_{1}-\mathrm{rpoB}_{2}, \mathrm{katG}_{1}-\mathrm{katG}_{2}$, dan $\mathrm{B}_{1}-\mathrm{B}_{2}$ serta karakterisasi menggunakan gel agarosa $2 \%$. Hasil penelitian menunjukkan bahwa $M$. tuberculosis yang resisten terhadap isoniazid dan rifampisin (MDR-TB) dapat diidentifikasi menggunakan PCR multipleks yang menghasilkan fragmen DNA dengan ukuran $71 \mathrm{pb}, 124 \mathrm{pb}, 186 \mathrm{pb}$, dan $200 \mathrm{pb}$, sedangkan untuk sampel non MDR-TB diperoleh fragmen DNA dengan ukuran 200 pb saja. Hasil penelitian ini menunjukkan bahwa identifikasi kasus MDR-TB dan non MDR-TB dapat dilakukan menggunakan PCR multipleks dengan kombinasi empat pasang primer.
\end{abstract}

Kata kunci: M. tuberculosis, MDR-TB, PCR multipleks.

\begin{abstract}
The incidence of multidrug-resistant tuberculosis (MDR-TB) cases has become the biggest source of the problem in the effort to eradicate tuberculosis (TB) disease in Indonesia. MDR-TB is a resistant TB bacteria to the two, at least, first-line TB drugs, e.g., rifampin and isoniazid. Unfortunately, the current diagnostics methods to identify the MDR-TB are still slow, unspecific, and inaccurate. The purpose of this study is to identify the isoniazid- and rifampin-resistant M. tuberculosis (local strain Balai Laboratorium Kesehatan Provinsi Jawa Barat) by using multiplex PCR method. The TB bacteria colonies were cultivated in Middlebrook $7 \mathrm{~h} 9$ broth media, which followed by the isolation of chromosomal DNA. The best PCR condition was achieved by optimizing the annealing temperature, the concentration of magnesium chloride, and a number of the cycle. Multiplex PCR was conducted with $\operatorname{inh}_{1}-\mathrm{inh}_{2}, \mathrm{rpoB}_{1^{-}} \mathrm{rpoB}_{2}$, katG $\mathrm{k}_{1^{-}} \mathrm{katG}_{2}$, and $\mathrm{B}_{1^{-}}-\mathrm{B}_{2}$ pair primers.
\end{abstract}


Furthermore, the PCR product was characterized on $2 \%$ gel agarose electrophoresis which stained by using ethidium bromide. The result showed that isoniazid- and rifampin-resistant $M$. tuberculosis sample could be identified using multiplex PCR, producing DNA fragments with a size of $71 \mathrm{bp}, 124 \mathrm{bp} 186 \mathrm{bp}$, and $200 \mathrm{bp}$. A non-MDR-TB only produced one DNA fragments with a size of $200 \mathrm{bp}$. Therefore, it can be concluded that MDR-TB and non-MDR-TB can be distinguished using multiplex PCR with a combination of four pair primers.

Keywords: M. tuberculosis, MDR-TB, multiplex PCR.

DOI: http://10.15408/jkv.v4i2.7226

\section{PENDAHULUAN}

Penyakit tuberkulosis (TB) masih merupakan masalah utama kesehatan masyarakat di Indonesia. Indonesia sebagai penyumbang $\mathrm{TB}$ terbesar ketiga di dunia setelah India dan Cina dengan jumlah kasus baru sekitar 1.017.378, serta jumlah kematian sekitar 160.830 orang per tahun (Collins, Hafidz and Mustikawati, 2017). Setiap tahunnya terdapat sekitar empat juta penderita baru tuberkulosis paru menular di dunia. Artinya, setiap tahun di dunia ini akan ada sekitar delapan juta penderita tuberkulosis paru dan akan ada sekitar tiga juta orang meninggal akibat penyakit ini. 490 ribu orang menderita MDR-TB di dunia pada tahun 2016, ditambah 110 ribu orang menderita $\mathrm{TB}$ resisten rifampisin(WHO, 2018). Estimasi prevalensi TB di Indonesia berdasarkan pemeriksaan mikroskopik BTA positif sebesar 148.5 per 100.000 orang. Survei Kesehatan Rumah Tangga (SKRT) tahun 1995 juga menyatakan bahwa penyakit TB sebagai penyebab kematian ketiga terbesar di Indonesia setelah penyakit kardiovaskuler dan penyakit saluran pernafasan serta penyakit nomor satu terbesar dalam kelompok penyakit infeksi.

Program pemberantasan tuberkulosis nasional menjadi lebih rumit dilakukan akibat muncul fenomena bakteri $M$. tuberculosis yang resisten terhadap berbagai obat anti tuberkulosis (OAT) yang lebih dikenal dengan istilah multidrug resistant tuberculosis (MDRTB). Berdasarkan data Depkes RI (2007), Indonesia menduduki peringkat ke 8 dari 27 negara-negara yang mempunyai beban tinggi (85\% dari beban MDR-TB global) dan prioritas kegiatan untuk MDR-TB. Kasus MDR-TB merupakan bentuk spesifik dari TB resisten obat yang terjadi jika bakteri TB resisten terhadap setidaknya isoniazid dan rifampisin, dua jenis obat anti tuberkulosis yang memiliki efektivitas paling tinggi dan utama digunakan. Resistensi obat terjadi akibat penggunaan OAT yang tidak tepat dosis pada pasien yang masih sensitif terhadap rejimen OAT. Ketidaksesuaian ini bisa ditimbulkan oleh berbagai sebab, seperti karena pemberian rejimen yang tidak tepat oleh tenaga kesehatan atau kegagalan dalam memastikan pasien menyelesaikan seluruh tahapan pengobatan. Pengobatan pada pasien MDR-TB bersifat lebih sukar daripada kasus TB biasa dan tidak hanya membahayakan bagi penderita sendiri tetapi juga menular bagi masyarakat sekitarnya. Sehubungan dengan hal ini, kasus MDR-TB harus diidentifikasi dengan benar dan cepat agar pengobatan dapat dilakukan dengan tepat dan segera mungkin.

Kemampuan untuk mendeteksi secara akurat infeksi bakteri TB menjadi sangat penting untuk mengendalikan epidemi tersebut, terutama terkait kasus MDR-TB. Cara yang cepat untuk mendeteksi infeksi bakteri tuberkulosis akan membantu mempercepat diagnosis dini pada pasien yang secara klinis suspek tuberkulosis dengan segera diikuti penatalaksanaan yang tepat. Diagnosis tuberkulosis khususnya tuberkulosis paru, dapat ditegakkan dengan pemeriksaan klinik (anamnesis terhadap keluhan penderita dan hasil pemeriksaan fisik pemeriksaan laboratorium) dan pemeriksaan radiologik. Ketiga hasil pemeriksaan tersebut disatukan untuk diagnosis tuberkulosis, namun keberadaan berbagai jenis metode diagnosis yang telah ada saat ini masih memiliki keterbatasan. Pemeriksaan mikroskopik cukup cepat dan ekonomis akan tetapi sensitivitas dan spesifitasnya masih kurang, pemeriksaan kultur memerlukan waktu yang cukup lama sekitar 3-12 minggu, sedangkan pemeriksaan radiologik terkadang sulit membedakan antara penyakit TB dan penyakit paru lainnya, sehingga penggunaan berbagai metode diagnosis ini perlu dilakukan konfirmasi dengan metode-metode lainnya (Sandegren et al., 2011). Akibatnya, secara keseluruhan 
penggunaan konfirmasi berbagai metode diagnosis akan membuat biaya yang digunakan akan semakin besar dan proses diagnosis yang semakin lebih lama. Selain itu, berbagai metode diagnosis yang telah ada saat ini hanya mampu mendeteksi keberadaan bakteri penyebab TB saja, adanya kasus pasien yang nonresisten atau MDR-TB tidak dapat dibedakan. Ini menjadi masalah yang penting, karena penanganan dalam upaya pengobatan yang dilakukan pada pasien TB nonresisten berbeda dibandingkan pasien MDR-TB (Kolyva and Karakouis, 2016). Oleh karena itu, untuk mengatasi keterbatasan tersebut diperlukan suatu metode deteksi bakteri tuberkulosis yang cepat, sensitif, spesifik, ekonomis dan mampu mendeteksi adanya kasus resisten antibiotik.

PCR multipleks dapat mengamplifikasi beberapa gen yang berbeda menggunakan berbagai primer spesifik dalam satu kali reaksi. Dalam kerjanya, primerprimer ini akan menempel pada urutan DNA target pada gen yang diinginkan sehingga dihasilkan perbanyakan DNA yang dapat diidentifikasi pada panjang fragmen tertentu melalui tahap elektroforesis. PCR multipleks dapat mempercepat proses diagnosis berbagai kasus resisten obat dalam sekali proses, sehingga waktu proses identifikasi yang cepat $( \pm 2.5$ jam $)$, ekonomis karena tidak memerlukan konversi dari uji-uji lain, sensitivitas hasil analisis dengan akurasi tinggi (>95\%) dan ramah lingkungan karena tidak menggunakan bahan radioaktif berbahaya. Selain itu, metode ini dapat mendeteksi tidak hanya keberadaan bakteri tuberkulosis dalam spesimen klinis saja akan tetapi juga dapat menentukan resistensinya tehadap OAT berdasarkan adanya mutasi gen penyandi sasaran OAT pada bakteri tuberkulosis. PCR multipleks telah berhasil digunakan untuk deteksi cepat isolat klinis TB resisten isoniazid (Herrera-Leon, Jimenez, Molina, Saiz, \& SaezNieto, 2005).Disain dan evaluasi tiga pasang primer dalam satu proses PCR telah dilakukan untuk amplifikasi ekson 1 gen Hyaluroglucosaminidase-1 (Tambunan et al., 2010). Adanya metode diagnosis yang cepat ini akan membuat langkah penanganan pasien TB menjadi lebih berarti dan mampu meminimalisir efek penularan penyakit TB yang semakin besar di Indonesia.

Berdasarkan latar belakang yang telah dipaparkan, maka apakah metode PCR multipleks dapat digunakan untuk mengidentifikasi $M$. tuberculosis (galur lokal Balai Laboratorium Kesehatan Provinsi Jawa Barat) yang resisten terhadap isoniazid dan rifampisin serta bagaimana kondisi optimum yang dibutuhkan PCR multipleks untuk mengidentifikasi $M$. tuberculosis (galur lokal Balai Laboratorium Kesehatan Provinsi Jawa Barat) yang resisten terhadap isoniazid dan rifampisin. Maksud penelitian ini adalah mengembangkan metode diagnosis cepat $M$. tuberculosis galur lokal dengan menggunakan PCR multipleks sehingga dapat digunakan sebagai metode diagnosis rutin serta dapat menjadi dasar dalam pemilihan tindakan pengobatan yang paling tepat bagi pasien TB. Penelitian ini diharapkan dapat menghasilkan suatu metode diagnosis yang dapat digunakan untuk identifikasi kasus resistensi obat isoniazid dan rifampisin pada pasien MDR-TB sehingga dapat diaplikasikan pada diagnosis rutin penyakit TB di Indonesia.

\section{METODE PENELITIAN}

Penelitian bersifat eksperimen dan studi komparatif pada optimasi PCR multipleks untuk diagnosis MDR-TB. Subjek penelitian menggunakan sampel bakteri $M$. tuberculosis galur lokal Balai Laboratorium Kesehatan (BLK) Provinsi Jawa Barat yang terdiri atas kultur bakteri dengan kasus nonresisten (kode: K), monoresisten isoniazid (kode: 838), monoresisten rifampisin (kode: 1S), serta resisten isoniazid dan rifampisin (MDR-TB) (kode: 798) yang berasal dari kultur bakteri pada media Ogawa. Sampel ini telah divalidasi di laboratorium menggunakan berbagai antibiotik untuk mengetahui kasus resistensi yang terjadi. Kultur bakteri ini akan digunakan sebagai sampel sekaligus kontrol positif. Media yang digunakan dalam penelitian ini adalah media cair Middlebrook 7 h9 Broth Difco ${ }^{T M}$. Kultivasi M. tuberculosis dilakukan dengan cara memindahkan kultur bakteri TB pada media Ogawa (yang telah diketahui kasus resistensinya) ke dalam tabung reaksi untuk media kultivasi yang berisi media cair Middlebrook 7 h9 Broth Difco ${ }^{T M}$. Selanjutnya koloni $M$. tuberculosis diinkubasi dalam inkubator pada suhu $37{ }^{\circ} \mathrm{C}$ selama 3 minggu. DNA kromosom dari M. tuberculosis diisolasi menggunakan kit isolasi Roscheapplied-science version 16.0.

Proses amplifikasi gen IS6110 DNA kromosom M. tuberculosis hasil lisis dilakukan 
menggunakan primer $\mathrm{B}_{1}$ dan $\mathrm{B}_{2}$ yang biasa digunakan untuk identifikasi penyakit tuberkulosis (TB) secara universal. Produk PCR dikarakterisasi dengan elektroforesis pada konsentrasi gel agarosa $2 \% \quad(\mathrm{~b} / \mathrm{v}$ dan menggunakan marker $100 \mathrm{bp}$. Optimasi PCR multipleks dilakukan dengan variasi suhu annealing, konsentrasi magnesium klorida, dan jumlah siklus.

Primer-primer yang digunakan untuk identifikasi kasus resisten isoniazid dan rifampisin (MDR-TB) serta primer-primer yang digunakan untuk identifikasi kasus nonresisten dapat ditunjukkan pada Tabel 1 dan 2 (Bachmann et al., 2008; Shimizu et al., 2008).

Proses amplifikasi gen IS6110 DNA kromosom $M$. tuberculosis dilakukan untuk mengetahui keberadaan DNA kromosom $M$. tuberculosis yang telah mengalami proses lisis dari prosedur yang telah dilakukan sebelumnya. Konfirmasi ini dilakukan dengan PCR unipleks menggunakan primer $B_{1}$ dan $B_{2}$ yang telah teruji untuk identifikasi penyakit TB secara univeral dalam penelitian sebelumnya. Komposisi reagen satu kali reaksi PCR unipleks (volume total $50 \mu \mathrm{L}$ ) terdiri atas 29.6 $\mu \mathrm{L}$ akuabides, $5 \mu \mathrm{L}$ bufer PCR 10x (mengandung magnesium klorida $2 \mathrm{mM}$ ), $1 \mu \mathrm{L}$ larutan magnesium klorida $0,5 \mathrm{mM}$, masingmasing $1 \mu \mathrm{L}$ primer $\mathrm{B}_{1}$ dan $\mathrm{B}_{2}$ dengan konsentrasi $20 \mathrm{pmol} / \mu \mathrm{L}, 2 \mu \mathrm{L}$ campuran dNTP $200 \mu \mathrm{M}$ yang terdiri atas dATP, dGTP, dTTP, dan dCTP, enzim taq DNA polimerase digunakan sebanyak dua unit (setara $0.4 \mu \mathrm{L}$ dengan konsentrasi 5 unit/ $\mu \mathrm{L}$ ), dan $8 \mu \mathrm{L}$ templat DNA.

Pengondisian PCR unipleks dilakukan melalui tahap denaturasi awal pada $95^{\circ} \mathrm{C}$ selama 5 menit, kemudian masuk program siklus PCR sebanyak 35 siklus dengan tahap denaturasi pada $95{ }^{\circ} \mathrm{C}$ selama 30 detik, tahap annealing pada $58{ }^{\circ} \mathrm{C}$ selama 60 detik, extension pada $72{ }^{\circ} \mathrm{C}$ selama 60 detik, dan proses extension akhir pada $72{ }^{\circ} \mathrm{C}$ selama 7 menit. Produk PCR dikarakterisasi dengan elektroforesis pada konsentrasi gel agarosa $2 \%(\mathrm{~b} / \mathrm{v})$, tegangan $80 \mathrm{~V}$, arus $80 \mathrm{~mA}$, selama 45 menit, dan menggunakan marker $100 \mathrm{bp}$.

Tabel 1. Primer-primer yang digunakan untuk identifikasi kasus resisten isoniazid dan rifampisin (MDR-TB) (Shimizu et al., 2008).

\begin{tabular}{cccc}
\hline Primer & Urutan $\left(\mathbf{5}^{\prime} \rightarrow \mathbf{3}^{\prime}\right)$ & $\mathbf{T m} /{ }^{\mathbf{0}} \mathbf{C}$ & Panjang Fragmen \\
\hline inhA $_{1}$ & CGTCGACATACCGATTTCG & 60,87 & $71 \mathrm{pb}$ \\
$\mathrm{inh}_{2}$ & TCAGTGGCTGTGGCAGTCA & 66,37 & \\
$\mathrm{rpoB}_{1}$ & CGTCGACATACCGATTTCG & 63,48 & $124 \mathrm{pb}$ \\
$\mathrm{rpoB}_{2}$ & TCAGTGGCTGTGGCAGTCA & 68,26 & \\
$\mathrm{katG}_{1}$ & GGTCGCGACCATCGACGTTG & 68,47 & $186 \mathrm{pb}$ \\
$\mathrm{katG}_{2}$ & AACCGCTGCATGCCGC & 67,02 & \\
\hline
\end{tabular}

Tabel 2. Primer-primer digunakan untuk identifikasi kasus nonresisten (Bachmann et al., 2008).

\begin{tabular}{cccc}
\hline Primer & Urutan $\left(\mathbf{5}^{\prime} \rightarrow \mathbf{3}^{\prime}\right)$ & $\mathbf{T} \mathbf{m} /{ }^{\mathbf{0}} \mathbf{C}$ & Panjang Fragmen \\
\hline $\mathrm{B}_{1}$ & CTACCCGCTGTTCAACCTGT & 64,61 & \\
$\mathrm{~B}_{2}$ & AATTTCATCAGCCCCTTGTG & 60,93 & $200 \mathrm{pb}$ \\
\hline
\end{tabular}




\section{HASIL DAN PEMBAHASAN}

Galur M. tuberculosis dapat dibedakan dari galur mikobakteria lainnya melalui identifikasi gen IS6110, sedangkan adanya kasus resistensi dapat disebabkan oleh adanya mutasi (Tu, Hong, \& Chen, 2009). Resistensi terhadap isoniazid berhubungan secara global dengan mutasi pada gen katG315 (ditemukan hampir 64\%) selain itu mutasi pada gen inhA15 juga menyebabkan resisten terhadap isoniazid, kemudian kasus resistensi terhadap rifampisin berhubungan dengan terjadinya mutasi pada gen rpoB (ditemukan dominan pada $90 \%$ isolat klinis yang resisten terhadap rifampisin), sedangkan kasus resistensi terhadap isoniazid dan rifampisin sekaligus (MDR-TB) berhubungan dengan adanya mutasi pada gen inhA, katG, dan rpoB secara serentak (Fessenden and Fessenden, 1992; Seifert et al., 2015). Gen-gen ini berperan secara langsung terhadap mekanisme interaksi OAT dengan protein target pada $M$. tuberculosis. Adanya mutasi pada gen-gen ini menyebabkan bakteri menjadi resisten terhadap OAT (Smith et al., 2014).

DNA kromosom $M$. tuberculosis menjadi target DNA yang akan digunakan dalam metode diagnosis ini. Hal ini disebabkan mutasi-mutasi yang bertanggung jawab terhadap mekanisme resistensi OAT terjadi pada DNA kromosom. Tahap isolasi diawali dengan cara memisahkan koloni bakteri dari larutan media kultivasi untuk memudahkan proses isolasi.

Hasil karakterisasi PCR unipleks ini menggunakan primer universal $\mathrm{B}_{1}$ dan $\mathrm{B}_{2}$ pada suhu annealing $58{ }^{\circ} \mathrm{C}$, konsentrasi magnesium klorida $2.5 \mathrm{mM}$, dan jumlah 35 siklus PCR dapat ditunjukkan pada Gambar 1 dengan panjang fragmen DNA hasil lisis sebesar 200 pb. Hasil amplifikasi gen IS6110 DNA kromosom $M$. tuberculosis dari berbagai sampel menunjukkan bahwa seluruh tahap isolasi berlangsung baik dan dapat disimpulkan bahwa sampel merupakan bakteri $M$. Tuberculosis.

Karakterisasi hasil PCR dari DNA kromosom hasil lisis dibandingkan dengan marker 100 bp (lajur 2, Fermentas, Inc.). Lajur 3 merupakan sampel kode $\mathrm{K}$. Lajur 4 merupakan sampel kode 838. Lajur 5 merupakan sampel kode 1S. Lajur 6 merupakan sampel kode 790. Lajur 1 merupakan kontrol negatif. Semua isolat hasil lisis memiliki fragmen DNA dengan ukuran
$200 \mathrm{pb}$ yang mengindikasikan gen IS6110 M. tuberculosis. Dalam reaksi PCR multipleks digunakan kombinasi primer inhA, rpoB, dan katG. Oleh karena itu, terlebih dahulu dilakukan optimasi primer untuk mencari kondisi optimal dari masing-masing primer. Optimasi masing-masing primer dilakukan pada tabung yang terpisah, namun pada kondisi yang sama. Optimasi primer dilakukan berdasarkan variasi suhu annealing, variasi konsentrasi magnesium klorida, dan variasi siklus PCR.

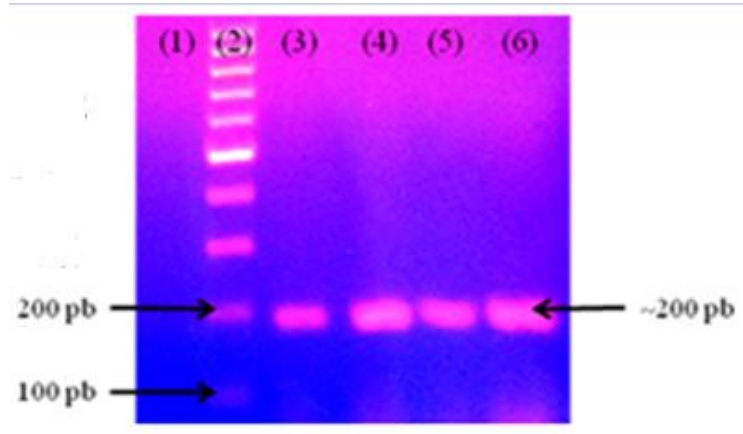

Gambar 1. Elektroforegram hasil PCR unipleks menggunakan primer universal $\mathrm{B}_{1}$ dan $\mathrm{B}_{2}$ pada suhu annealing $58^{\circ} \mathrm{C}$, konsentrasi magnesium klorida 2,5 $\mathrm{mM}$, dan jumlah 35 siklus PCR.

PCR unipleks dilakukan (Gambar 1) karena untuk mengetahui kondisi optimal masing-masing primer terlebih dahulu. Primer ini akan mengamplifikasi gen IS6110 yang merupakan gen paling conserved pada $M$. tuberculosis. Amplifikasi daerah gen ini dapat digunakan untuk membedakan $M$. tuberculosis dengan jenis mikobakteria lainnya (Bachmann et al., 2008). Hasil amplifikasi gen IS6110 DNA kromosom $M$. tuberculosis dari berbagai sampel menunjukkan bahwa seluruh tahap isolasi berlangsung baik dan dapat disimpulkan bahwa sampel merupakan bakteri $M$. tuberculosis karena memperlihatkan adanya satu pita DNA yang berada pada pita kedua marker $100 \mathrm{bp}$. Diperkirakan pita DNA hasil amplifikasi dengan primer $\mathrm{B}_{1}$ dan $\mathrm{B}_{2}$ memiliki panjang fragmen $200 \mathrm{pb}$ yang menunjukkan gen IS6110 pada masing-masing sampel.

Identifikasi terhadap timbulnya kasus resistensi pada $M$. tuberculosis dapat dilakukan dengan mengamplifikasi gen-gen spesifik dari DNA kromosom bakteri TB yang memiliki hubungan secara langsung dengan suatu keadaan resistensi terhadap OAT. Upaya 
identifikasi ini dapat dilakukan menggunakan metode Polymerase Chain Reaction (PCR). Melalui metode PCR, amplifikasi gen target dapat dilakukan secara cepat, spesifik, dan tidak memerlukan jumlah templat DNA yang terlalu tinggi. Metode PCR sangat dipengaruhi oleh faktor-faktor seperti preparasi templat DNA, desain primer, penentuan suhu annealing, jumlah siklus, komposisi campuran reagen PCR, dan faktor pengerjaan yang menentukan hasil analisis PCR. Dalam prinsip kerjanya, tidak ada protokol baku yang dapat digunakan untuk setiap sampel dalam metode PCR, oleh karena itu setiap aplikasi PCR memerlukan tahap optimasi. Optimasi bertujuan untuk mendapatkan kondisi PCR yang optimal sehingga dihasilkan produk PCR spesifik, yaitu terbentuk pita DNA yang tebal dengan ukuran yang sesuai diharapkan dan tidak terbentuk dimer primer, smear atau multifragmen.

Produk PCR sangat bergantung pada penempelan primer dengan urutan templat, kemungkinan akan berkurang jumlahnya apabila terjadi reaksi antar sesama primer. Syarat-syarat primer yang baik antara lain panjang urutan basa primer adalah sekitar 1820 pasang basa, spesifitas urutan basa harus tinggi untuk menghindari bergabungnya primer pada daerah yang tidak diinginkan terutama pada bagian ujung 3', persentase kandungan $\mathrm{G}$ dan $\mathrm{C}$ kedua primer antara 45$60 \%$, nilai $\mathrm{Tm}$ kedua primer sebaiknya sama atau saling mendekati, dan konsentrasi optimal primer yang dipersyaratkan dalam reaksi adalah antara $0.1-0.5 \mu \mathrm{M}$. Konsentrasi yang tinggi akan mengakibatkan kesalahan menempel sehingga dapat menyintesis produk yang tidak diinginkan (Maksum et al., 2017)

Beberapa parameter yang penting untuk mengetahui sifat primer yang digunakan adalah persentase GC, Tm masing-masing primer dan kemungkinan terjadinya loop/self annealing (Maksum et al., 2017). Primerprimer ini memiliki persentase GC lebih dari $50 \%$ yang berarti telah menunjukkan syarat primer yang baik dalam kuatnya ikatan primer dengan templat sewaktu reaksi PCR. Energi bebas Gibbs (dG) menunjukkan energi pembentukan dan penguraian primer terhadap templat. Tanda negatif menunjukkan spontanitas reaksi. Makin tinggi nilai $\mathrm{dG}$, maka kecenderungan reaksi juga makin besar. Suhu annealing berpengaruh terhadap penempelan primer pada DNA yang akan diperpanjang. Penggunaan suhu annealing terlalu rendah akan menyebabkan primer tidak dapat menempel, sedangkan apabila terlalu tinggi akan menyebabkan primer terdenaturasi (Maksum, 2017; Maksum et al., 2017).

Penentuan suhu annealing yang optimal untuk pengerjaan PCR dapat dilakukan menggunakan software bebas lisensi melalui simulasi komputer, dengan harapan diperoleh data temperature melting $(\mathrm{Tm})$ masing-masing primer dan juga gabungan primer secara cepat dan akurat. Selanjutnya dengan program tersebut dapat diperoleh suhu annealing optimal teoritis yang menjadi pendukung dalam pencarian suhu annealing menggunakan PCR. Suhu annealing pada pengerjaan PCR ditentukan dengan terlebih dahulu mencari masing-masing Tm primer maupun Tm kombinasi primer yang dapat diketahui menggunakan program software Perlprimer. Hasil analisis primer menggunakan software Perlprimer ditunjukkan pada Tabel 3.

Setelah memasukkan urutan primer ke dalam program komputer, diperoleh data Tm primer forward inhA $A_{l}$ dengan urutan 5'CGTGGACATACCGATTTCG-3' adalah sekitar $60,87^{\circ} \mathrm{C}$, primer reverse $i n h A_{2}$ 5'TCAGTGGCTGTGGCAGT CA-3' sekitar $66,37^{\circ} \mathrm{C}$, primer forward $r p o B_{1}$ dengan urutan 5'- CGTCGACATA CCGATTTCG-3' adalah sekitar $63,48^{\circ} \mathrm{C}$, primer reverse $r p o B_{2}$ ' ${ }^{\prime}$ TCAGTGG CTGTGGCAGTCA-3' sekitar $68,26^{\circ} \mathrm{C}$, primer forward $\mathrm{kat}_{1}$ dengan urutan 5'-GGTCGCGACCATCGACGTTG-3' adalah sekitar $68,47^{\circ} \mathrm{C}$, dan primer reverse $\mathrm{kat}_{2} \mathrm{5}^{\prime}$ AACCGCTGCATGCCGC-3' sekitar $67,02^{\circ} \mathrm{C}$.

Optimasi suhu annealing dilakukan variasi suhu annealing pada rentang $65-60^{\circ} \mathrm{C}$ secara terpisah menggunakan masing-masing primer (PCR unipleks). Data hasil pengoptimalan suhu annealing menggunakan primer inhA, rpoB, dan katG pada berbagai variasi ditunjukkan pada Tabel 4. Hasil optimasi suhu annealing terbaik untuk masingmasing primer adalah pada kondisi suhu $62^{\circ} \mathrm{C}$. 
Tabel 3. Data hasil analisis primer menggunakan software Perlprimer.

\begin{tabular}{|c|c|c|c|c|c|c|c|}
\hline $\begin{array}{l}\text { Nama } \\
\text { Primer }\end{array}$ & $\sum$ Basa & $\mathrm{Tm} /{ }^{\circ} \mathrm{C}$ & $\begin{array}{c}\text { GC/ } \\
\%\end{array}$ & $\begin{array}{l}\text { Self.comp/ } \\
\text { (kkal/mol) }\end{array}$ & dS $\%$ eu & $\begin{array}{c}\mathrm{dH}^{\circ} / \\
\text { (kkal/mol) }\end{array}$ & $\begin{array}{c}\mathrm{dG}^{0} 37 / \\
\text { (kkal/mol }\end{array}$ \\
\hline $\operatorname{inh} A_{1}$ & 19 & 60.87 & 52 & $\begin{array}{l}-2.55 \\
-1.13\end{array}$ & -423.81 & -151.80 & -20.35 \\
\hline $\operatorname{inh}_{2}$ & 19 & 66.37 & 57 & $\begin{array}{l}-6.25 \\
-1.13\end{array}$ & -402.31 & -147.00 & -22.22 \\
\hline $\mathrm{rpoB}_{1}$ & 18 & 63.48 & 61 & $\begin{array}{l}-4.03 \\
-1.65 \\
-3.29\end{array}$ & -399.80 & -144.90 & -20.90 \\
\hline $\mathrm{rpoB}_{2}$ & 18 & 68.26 & 72 & $\begin{array}{l}-5.07 \\
-1.65\end{array}$ & -404.90 & -148.70 & -23.12 \\
\hline $\mathrm{katG}_{1}$ & 20 & 68.47 & 65 & $\begin{array}{l}-2.02 \\
-12.07 \\
-2.37\end{array}$ & -456.73 & -166.50 & -24.85 \\
\hline $\mathrm{katG}_{2}$ & 16 & 67.02 & 68 & $\begin{array}{l}-6.68 \\
-2.37\end{array}$ & -353.86 & -130.80 & -21.05 \\
\hline
\end{tabular}

Tabel 4. Hasil optimasi berbagai suhu annealing menggunakan primer inhA, rpoB, dan katG (pada konsentrasi magnesium klorida $2.5 \mathrm{mM}$ dan jumlah siklus PCR sebanyak empat puluh siklus).

\begin{tabular}{ccc}
\hline Suhu Annealing & Nama Primer & Hasil \\
\hline \multirow{2}{*}{$65^{\circ} \mathrm{C}$} & inhA & Ada fragmen sangat tipis \\
& rpoB & Multifragmen $($ smear $)$ \\
& katG & Tidak ada fragmen \\
& inhA & Ada fragmen sangat tipis \\
& rpoB & Multifragmen $($ smear $)$ \\
& katG & Tidak ada fragmen \\
& inhA & Ada fragmen sangat tipis \\
& rpoB & Multifragmen $($ smear $)$ \\
$63{ }^{\circ} \mathrm{C}$ & katG & Tidak ada fragmen \\
& inhA & Multifragmen $($ smear $)$ \\
& rpoB & Ada fragmen tebal \\
& $\mathbf{6 a t G}$ & Ada fragmen tebal \\
& inhA & Multifragmen $($ smear $)$ \\
& rpoB & Ada fragmen tipis \\
& katG & Ada fragmen sangat tipis \\
$61{ }^{\circ} \mathrm{C}$ & inhA & Multifragmen $($ smear $)$ \\
& rpoB & Ada fragmen tipis \\
& katG & Ada fragmen tipis \\
& & \\
& &
\end{tabular}

Berdasarkan data pada Tabel 4, hasil optimasi suhu annealing terbaik untuk masingmasing primer adalah pada kondisi suhu $62{ }^{\circ} \mathrm{C}$. Suhu tersebut dipilih sebagai suhu annealing untuk reaksi PCR yang akan dilakukan pada tahap selanjutnya. Pada suhu annealing ini, primer rpoB menunjukkan fragmen DNA tebal yang diperkirakan berukuran 124 pb dan primer katG menunjukkan fragmen DNA tebal yang diperkirakan berukuran 186 pb. Kedua fragmen DNA ini merupakan fragmen DNA dengan ukuran yang diinginkan, namun keberadaan pita spesifik primer inhA masih belum optimal, karena masih dalam bentuk multifragmen (smear). Oleh karena itu perlu dilakukan optimasi primer pada variasi kondisi PCR yang lainnya.

Optimasi kondisi PCR pada variasi konsentrasi magnesium klorida dilakukan pada rentang konsentrasi 2.0-4.0 mM secara terpisah 
menggunakan masing-masing primer (PCR unipleks). Hasil optimasi konsentrasi magnesium klorida menggunakan primer inhA, rpoB, dan katG pada berbagai variasi ditunjukkan oleh Tabel 5. Hasil optimasi pada variasi konsentrasi magnesium klorida untuk masing-masing primer menunjukkan hasil terbaik pada konsentrasi magnesium klorida $2.5 \mathrm{mM}$.

Beberapa penyebab timbulnya pita smear (multifragmen) dari elektrofogram antara lain suhu annealing yang tidak cocok, terlalu banyak $\mathrm{Mg}^{2+}$, terlalu banyak siklus, terlalu banyak templat, terlalu banyak enzim, dan waktu extension yang terlalu panjang. Oleh karena itu, tahap selanjutnya harus dilakukan optimasi kondisi PCR pada variasi konsentrasi magnesium klorida (Maksum, 2017; Maksum et al., 2017).

Magnesium klorida berfungsi sebagai kofaktor bagi enzim taq DNA polimerase, melarutkan dNTP, dan meningkatkan interaksi antara primer dan templat. Konsentrasi magnesium klorida harus dioptimasi untuk setiap pasang primer karena komponen reaksi PCR akan mengikat ion magnesium, termasuk primer, templat DNA, produk PCR, dan dNTP. Konsentrasi magnesium klorida yang optimal bervariasi antara $0.5-5 \mathrm{mM}$. Konsentrasi magnesium klorida juga mempengaruhi spesifitas dan jumlah produk (yield) PCR. Pada umumnya jika ion $\mathrm{Mg}^{2+}$ kurang akan menurunkan jumlah produk PCR, sedangkan apabila jumlahnya berlebih akan menurunkan spesifitas dan menghasilkan produk non spesifik akibat tingginya konsentrasi dNTP di sekitar enzim taq DNA polimerase sehingga terjadi kesalahan sintesis DNA. Optimasi kondisi PCR pada variasi konsentrasi magnesium klorida dilakukan pada rentang konsentrasi 2.0-4.0 mM (Maksum, 2017; Maksum et al., 2017).

Optimasi variasi jumlah siklus dilakukan pada 40, 35, dan 30 siklus secara terpisah menggunakan masing-masing primer (PCR unipleks). Hasil optimasi pada variasi jumlah siklus ditunjukkan pada Tabel 6 dengan jumlah siklus terbaik untuk masing-masing primer adalah pada 30 siklus, selanjutnya hasil ini dipilih sebagai jumlah siklus untuk reaksi PCR yang akan dilakukan pada tahap selanjutnya (PCR multipleks).

Hasil optimasi pada variasi konsentrasi magnesium klorida pada Tabel 5 untuk masing-masing primer menunjukkan hasil terbaik pada konsentrasi magnesium klorida 2,5 mM. Namun keberadaan pita spesifik primer inhA masih belum memuaskan karena masih dalam bentuk multifragmen (smear). Oleh karena itu, harus dilakukan optimasi primer pada variasi jumlah siklus PCR.

Tabel 5. Hasil optimasi berbagai konsentrasi magnesium klorida menggunakan primer inhA, rpoB, dan katG (pada suhu annealing $62^{\circ} \mathrm{C}$ dan jumlah siklus PCR sebanyak empat puluh siklus).

\begin{tabular}{ccc}
\hline Konsentrasi Magnesium Klorida & Nama Primer & Hasil \\
\hline \multirow{2}{*}{$2.0 \mathrm{mM}$} & inhA & Multifragmen (smear) \\
& rpoB & Ada fragmen tipis \\
& katG & Tidak ada fragmen \\
& inhA & Multifragmen (smear) \\
& rpoB & Ada fragmen tebal \\
& katG & Ada fragmen tebal \\
& inhA & Multifragmen (smear) \\
& rpoB & Ada fragmen tipis \\
& katG & Ada fragmen tipis \\
& inhA & Multifragmen (smear) \\
& rpoB & Multifragmen (smear) \\
& katG & Ada fragmen tipis \\
& inhA & Multifragmen (smear $)$ \\
& rpoB & Multifragmen (smear $)$ \\
& katG & Ada fragmen tipis \\
\hline
\end{tabular}


Tabel 6. Hasil optimasi berbagai jumlah siklus PCR menggunakan primer inhA, rpoB, dan katG (pada suhu annealing $62{ }^{\circ} \mathrm{C}$ dan konsentrasi magnesium klorida $2.5 \mathrm{mM}$ ).

\begin{tabular}{ccc}
\hline Jumlah Siklus & Nama Primer & Hasil \\
\hline \multirow{2}{*}{40} & inhA & Multifragmen (smear) \\
& rpoB & Ada fragmen tebal \\
& katG & Ada fragmen tebal \\
& inhA & Multifragmen (smear) \\
& rpoB & Ada fragmen tebal \\
& katG & Ada fragmen tebal \\
& inhA & Ada fragmen tipis \\
& rpoB & Ada fragmen tebal \\
& katG & Ada fragmen tebal \\
\hline
\end{tabular}

Pada jumlah tiga puluh siklus PCR (Tabel 6), optimasi primer rpoB menunjukkan fragmen DNA yang tebal yang diperkirakan berukuran $124 \mathrm{pb}$, primer katG menunjukkan fragmen DNA yang tebal yang diperkirakan berukuran $186 \mathrm{pb}$, dan primer inhA pada menunjukkan fragmen DNA yang tipis namun tidak terjadi smear yang diperkirakan berukuran $71 \mathrm{pb}$. Ketiga fragmen DNA spesifik ini merupakan fragmen DNA dengan ukuran yang diinginkan untuk mengamplifikasi gen target resisten isoniazid dan rifampisin (MDR-TB). Optimasi pada jumlah siklus 25 tidak dilakukan karena pengurangan jumlah siklus dapat menyebabkan perolehan fragmen DNA akan semakin sedikit sehingga pada tahap karakterisasi gel agarosa selanjutnya, fragmen DNA ini akan semakin sulit diidentifikasi. Dari hasil ini dapat disimpulkan bahwa kondisi ini merupakan kondisi PCR hasil optimasi terbaik yang dapat digunakan untuk tahap berikutnya. ada penelitian ini, PCR multipleks menggunakan tiga pasang primer, yaitu inhA, $r p o B$, dan $k a t G$ secara bersamaan dalam satu tabung. Tujuan digunakannya PCR multipleks adalah untuk mempercepat proses diagnosis berbagai kasus resisten obat dalam sekali proses. PCR multipleks dapat mengamplifikasi beberapa gen yang berbeda menggunakan berbagai primer spesifik dalam satu kali reaksi. Dalam kerjanya, primer-primer ini akan menempel pada urutan DNA target pada gen yang diinginkan sehingga dihasilkan perbanyakan DNA yang dapat diidentifikasi pada panjang fragmen tertentu melalui tahap elektroforesis.

Bagian gen yang conserved dari urutan DNA bakteri $M$. tuberculosis seperti gen katG dan inhA (kasus resistensi isoniazid (Stagg HR,
Lipman and McHugh, 2017; Tseng et al., 2015) rpoB (kasus resistensi rifampisin) (Li et al., 2012) atau dari sekuens sisipan/insertion sequence seperti IS6110 (nonresisten) (Bachmann et al., 2008). dapat digunakan sebagai gen penyandi adanya kasus resistensi antibiotik sehingga dapat digunakan untuk identifikasi kasus resistensi obat.

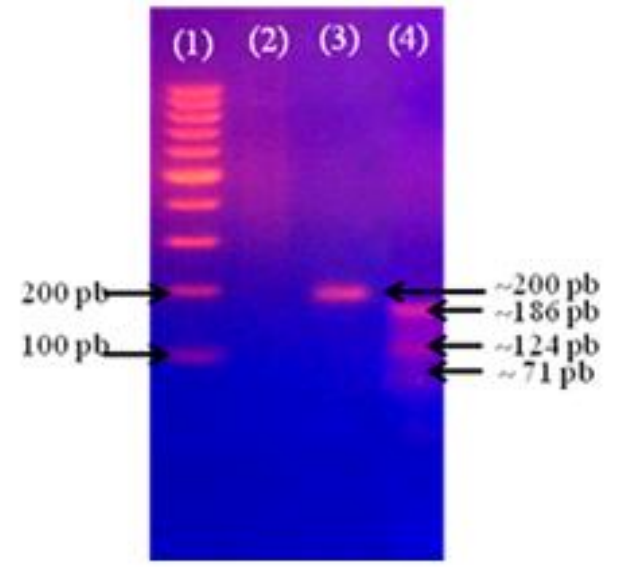

Gambar 2. Elektroforegram hasil PCR sampel kode 798 menggunakan tiga pasang primer (inhA, rpoB, dan katG) dibandingkan dengan sampel kode $\mathrm{K}$ menggunakan empat pasang primer (inhA, rpoB, katG, dan B) pada PCR multipleks dengan kondisi PCR hasil optimasi (suhu annealing $62{ }^{\circ} \mathrm{C}$, konsentrasi magnesium klorida 2.5 mM, dan siklus PCR sebanyak tiga puluh).

Karakterisasi hasil PCR dari templat DNA dibandingkan dengan marker $100 b p$ (lajur 1, Fermentas, Inc.). Lajur 2 merupakan kontrol negatif PCR. Lajur 3 merupakan 
kontrol negatif MDR-TB (sampel kode K) dengan panjang fragmen $200 \mathrm{pb}$. Lajur 4 merupakan kontrol positif MDR-TB (sampel kode 798) dengan panjang fragmen $71 \mathrm{pb}, 124$ pb, dan 186 pb. Hasil ini menunjukkan primer inhA, rpoB, dan katG dapat bekerja optimal pada sistem PCR multipleks. Hasil lain yang sangat menarik ditunjukkan oleh pasangan primer B yang ternyata juga dapat bekerja pada kondisi PCR multipleks yang sama menggunakan kombinasi empat pasang primer sehingga dapat membedakan kasus MDR-TB dan non MDR-TB secara langsung.

Dari hasil identifikasi menggunakan PCR multipleks (Gambar 2) diperoleh fragmen DNA spesifik dangan ukuran $71 \mathrm{pb}, 124 \mathrm{pb}$ dan $186 \mathrm{pb}$ yang mengindikasikan adanya kasus resistensi terhadap isoniazid dan rifampisin pada sampel 798 (MDR-TB), sedangkan pada sampel K (non MDR-TB) tidak ditemukan adanya fragmen DNA spesifik dengan ukuran fragmen yang diinginkan. Hal ini mengindikasikan bahwa primer inh A, rpoB dan katG yang digunakan secara bersamaan dalam PCR multipleks telah berhasil digunakan untuk mengidentifikasi gen inhA, $r p o B$ dan katG yang berperan terhadap munculnya kasus MDR-TB pada $M$. tuberculosis.

Hal lain yang menarik dari data yang diperoleh pada Gambar 2 adalah ditemukannya pita hasil amplifikasi primer $B$, inhA, rpoB dan katG pada sampel non MDR-TB (sampel kode $\mathrm{K})$ dengan ukuran fragmen $200 \mathrm{pb}$ yang mengindikasikan kasus non MDR-TB (nonresisten). Walaupun dilakukan amplifikasi kondisi PCR yang berbeda dengan prosedur sebelumnya, ternyata primer $\mathrm{B}$ juga dapat bekerja pada kondisi PCR multipleks hasil optimasi yang digunakan. Ini memberikan suatu kemungkinan baru bahwa primer ini juga dapat digunakan pada kondisi PCR multipleks yang sama menggunakan kombinasi primer B, inhA, rpoB, dan katG untuk membedakan sampel MDR-TB dan non MDR-TB secara langsung.

Hasil karakterisasi PCR sampel DNA TB resisten isoniazid dan rifampisin (MDRTB) pada PCR multipleks menggunakan empat pasang primer ditunjukkan pada Gambar 3 . Identifikasi DNA kromosom M. tuberculosis sampel kode 798 yang resisten terhadap isoniazid dan rifampisin (MDR-TB) menggunakan PCR multipleks dengan kombinasi empat pasang primer (inhA, rpoB,
$\mathrm{katG}$, dan B) telah berhasil, ditandai dengan adanya empat fragmen DNA spesifik dengan ukuran 71 pb, 124 pb, 186 pb, dan 200 pb.

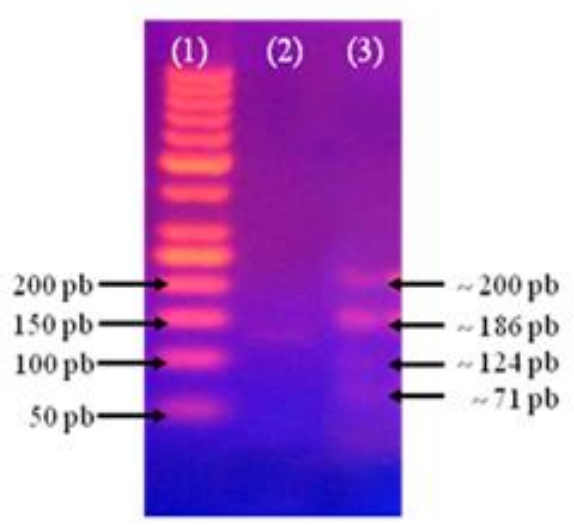

Gambar 3. Elektroforegram hasil PCR sampel 798 pada PCR multipleks menggunakan empat pasang primer (inhA, rpoB, katG, dan B) pada kondisi PCR hasil optimasi (suhu annealing $62 \quad{ }^{\circ} \mathrm{C}$, konsentrasi magnesium klorida 2.5 $\mathrm{mM}$, dan siklus PCR sebanyak tiga puluh).

Pada Gambar 3 menunjukkan bahwa identifikasi DNA kromosom M. tuberculosis sampel kode 798 yang resisten terhadap isoniazid dan rifampisin (MDR-TB) dapat dilakukan dengan PCR multipleks menggunakan kombinasi empat pasang primer (inhA, rpoB, katG, dan B), ditandai dengan adanya empat fragmen DNA spesifik dengan ukuran 71 pb, 124 pb, 186 pb, dan 200 pb. Dengan demikian, maka dapat disimpulkan bahwa PCR multipleks juga dapat bekerja optimal menggunakan empat pasang primer sehingga dapat membedakan antara kasus MDR-TB (empat fragmen DNA dengan ukuran $71 \mathrm{pb}, 124 \mathrm{pb}, 186 \mathrm{pb}$, dan $200 \mathrm{pb}$ ) dan kasus non MDR-TB (satu fragmen DNA saja dengan ukuran $200 \mathrm{pb}$ ) secara langsung pada kondisi PCR yang sama dalam suatu sampel.

Isolat klinis yang telah terbukti memiliki kasus resistensi isoniazid dan rifampisin (pita DNA $71 \mathrm{pb}, 124 \mathrm{pb}, 186 \mathrm{pb}$, dan $200 \mathrm{pb}$ ) sebaiknya direkomendasikan pemberian tindakan pengobatan menggunakan OAT lini pertama selain isoniazid dan rifampisin, sedangkan pada isolat klinis yang non MDR-TB sebaiknya direkomendasikan pemberian tindakan pengobatan menggunakan OAT lini pertama, yakni isoniazid dan atau rifampisin. 
Mutasi pada gen inhA dari $M$. tuberculosis yakni mutasi A1022G, C1023T, T1030A, dan T1030G (ditemukan pada isolat klinis resistensi terhadap isoniazid), mutasi pada gen rpoB yakni mutasi C180A, C180G, C180T, A181C, A190T, C191A, C201T, C208T, C218G, A220C, C221A, C221G, A222C, C219A, C219G, C219T, A220C, A220G, C235G, C235T, dan T241C (ditemukan pada isolat klinis resisten rifampisin), serta mutasi pada gen katG yakni mutasi A281C, C322G, C324G, dan G369C T1030G (ditemukan pada isolat klinis resisten terhadap isoniazid). Pada penelitian ini, analisis terhadap varian mutasi M. tuberculosis galur lokal Balai Laboratorium Kesehatan Provinsi Jawa Barat tidak dilakukan, sehingga varian mutasi yang terjadi pada galur ini belum dapat ditentukan. Oleh karena itu, pada tahap penelitian selanjutnya perlu dilakukan analisis varian mutasi yang berhubungan dengan kasus resisten OAT pada M. tuberculosis galur lokal Balai Laboratorium Kesehatan Provinsi Jawa Barat. Dari hasil peneltian ini juga dapat dikembangkan pada isolat klinis galur lainnya yang ada di Indonesia.

\section{SIMPULAN}

Dari hasil penelitian yang telah dilakukan, maka dapat disimpulkan bahwa metode PCR multipleks dapat digunakan untuk mengidentifikasi $M$. tuberculosis (galur lokal Balai Laboratorium Kesehatan Provinsi Jawa Barat) yang resisten terhadap isoniazid dan rifampisin (MDR-TB) ditandai dengan diperolehnya fragmen DNA dengan ukuran 71 pb, $124 \mathrm{pb}, 186 \mathrm{pb}$, dan $200 \mathrm{pb}$, sedangkan untuk kasus non MDR-TB diperoleh fragmen DNA dengan ukuran 200 pb saja. Kondisi optimum yang didapat untuk masing-masing primer adalah pada suhu annealing $62{ }^{\circ} \mathrm{C}$, konsentrasi magnesium klorida $2.5 \mathrm{mM}$, dan 30 siklus.

\section{UCAPAN TERIMA KASIH}

Penulis mengucapkan terima kasih kepada Dirjen DIKTI, Pimpinan Universitas Padjadjaran, Ketua Lembaga Penelitian Unpad, Dekan FMIPA Unpad, Ketua Departemen Kimia serta Kepala Laboratorium dan seluruh staf Laboratorium Balai Laboratorium Kesehatan Provinsi Jawa Barat yang telah membantu terlaksananya penelitian ini.

\section{DAFTAR PUSTAKA}

Bachmann L, Däubl B, Lindqvist C, Kruckenhauser L, Teschler-Nicola M, Haring E. 2008. PCR diagnostics of Mycobacterium tuberculosis in historic human long bone remains from 18th century burials in Kaiserebersdorf, Austria. BMC Research Notes. 1: 1-6. https://doi.org/10.1186/1756-0500-1-83.

Collins D, Hafidz F, Mustikawati D. 2017. The economic burden of tuberculosis in Indonesia. The International Journal of Tuberculosis and Lung Disease, 21(9), 10411048. https://doi.org/10.5588/ijtld.16.0898.

Fessenden R, Fessenden J. 1992. Kimia Organik Jilid 1. Jakarta(ID): Erlangga.

Herrera-Leon L, Jimenez M, Molina T, Saiz P, Saez-Nieto J. 2005. New multiplex PCR for rapid detection of isoniazid-resistant Mycobacterium tuberculosis clinical isolates. Antimicrobial Agents and Chemotherapy, 49(1): 144-147. https://doi.org/10.1093/nar/15.3.1311

Kolyva AS, Karakouis PC. 2016. Old and new drugs : mechanism of action and resistance. Intechopen. $9(10)$ : 209-232. https://doi.org/10.5772/711.

Li J, Xin J, Zhang L, Jiang L, Cao H, Li L. 2012. Rapid detection of rpoB mutations in rifampin resistant $M$. tuberculosis from sputum samples by denaturing gradient gel electrophoresis. International Journal of Medical Sciences. 9(2): 148-156. https://doi.org/10.7150/ijms.3605.

Maksum I. 2017. PCR Dalam Investigasi Penyakit Mitokondria. Jatinangor (ID): Alqaprint, Cakrawala Baru Dunia Buku.

Maksum IP, Sriwidodo, Gaffar S, Hassan K, Subroto T, Soemitro S. 2017. Teknik Biologi Molekular. (AA Wildan, Ed.) (1st ed.). Jatinangor (ID): Alqaprint Jatinangor.

Sandegren L, Groenheit R, Koivula T, Ghebremichae S, Advani A, Castro E, Källenius G. 2011. Genomic stability over 9 years of an isoniazid resistant mycobacterium tuberculosis outbreak strain in Sweden. PLoS ONE, https://doi.org/10.1371/journal.pone.0016647.

Seifert M, Catanzaro D, Catanzaro A, Rodwell TC. 2015. Genetic mutations associated with isoniazid resistance in Mycobacterium 
tuberculosis: A systematic review. PLoS ONE, 10(3): 1-13. https://doi.org/10.1371/journal.pone.0119628.

Shimizu Y, Dobashi K, Yoshikawa Y, Yabe S, Higuchi S, Koike Y, Mori M. 2008. Fiveantituberculosis drug-resistance genes detection using array system. Journal of Clinical Biochemistry and Nutrition, 42(3), 228-34.

https://doi.org/10.3164/jcbn.2008033.

Smith T, Wolff K, Nguyen L. 2014. Molecular Biology of Drug Resistance in Mycobacterium tuberculosis. 374: 53-80.

Stagg HR, Lipman MC, McHugh TD, and J. H. (2017). Isoniazid resistant tuberculosis- a cause for concern. Int J.T. Uberc Lung Dis. 21(2): 129-139. https://doi.org/10.5588/ijtld.16.0716.Isoniazid

Tambunan USF, Sugito S, Parikesit AA. 2010.
Design and Evaluation of Three Pair Primers for Exon 1 Amplification of Hyaluroglucosaminidase-1 Gene. OnLine Journal of Biological Sciences. 10(2): 66-72.

Tseng ST, Tai CH, Li CR, Lin CF, Shi ZY. 2015. The mutations of katG and inhA genes of isoniazid-resistant Mycobacterium tuberculosis isolates in Taiwan. Journal of Microbiology, Immunology and Infection, 48(3): 249-255. https://doi.org/10.1016/j.jmii.2013.08.018

Tu YK, Hong YY, Chen YC. 2009. Finite element modeling of kirschner pin and bone thermal contact during drilling. Life Science Journal. 6(4): 23-27. https://doi.org/10.1007/82

WHO. 2018. Tubercolusis (Tb) Seventy-first World Health Assembly commits to accelerate action to End TB. Retrieved from http://www.who.int/tb/en/ 